\title{
ARTIGO
}

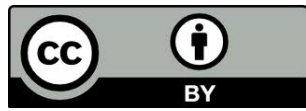

\section{A LIBERDADE RELIGIOSA NO BRASIL: CORRELAÇÕES ENTRE JURISPRUDÊNCIA E COLISÃO DE DIREITOS FUNDAMENTAIS}

\author{
Religious liberty in Brazil: correlations between jurisprudence and collision of \\ fundamental rights
}

Janine Andreiv Rodrigues Mestrado em Desenvolvimento Sustentável pela Universidad Nacional de Lanus, Professora Bolsita na Tutoria do Curso Técnico em Serviçso Públicos do IFPR, Professora Colaboradora na Universidade Tuiti - Curitiba nine_janine@hotmail.com

\begin{abstract}
RESUMO: Um Estado laico, como o Brasil, ao se afirmar como tal, tem o compromisso de separar Estado e religião e de proteger a liberdade religiosa, garantindo esse direito a todos os seus cidadãos. A liberdade religiosa é a liberdade de professar qualquer religião, de realizar os cultos ou tradições referentes a essas crenças, de manifestar-se, em sua vida pessoal, conforme seus preceitos e poder viver de acordo com essas crenças. O presente artigo pretende abordar os seguintes conceitos: - O que são Direitos Fundamentais. Bem como, a incorporação dos tratados internacionais de direitos humanos. Como o próprio título denota: Uma abordagem a Colisão de Direitos Fundamentais no que tange a liberdade religiosa no Brasil, estudaremos o que é liberdade religiosa, sua evolução como um dos primeiros direitos fundamentais, que surgem com o constitucionalismo e os direitos de defesa, a colisão de direitos fundamentais, a eficácia das normas constitucionais e de que forma a Jurisprudência trata desta colisão no que tange a liberdade religiosa no Brasil.
\end{abstract}

Palavras-chave: Direitos Fundamentais; Liberdade Religiosa; Colisão de Direitos Fundamentais; Jurisprudência Liberdade Religiosa no Brasil.

ABSTRACT: A secular state, like Brazil, asserting itself as such, is committed to separating State and religion and to protecting religious freedom, guaranteeing this right to all its citizens. Religious freedom is the freedom to profess any religion, to perform the cults or traditions pertaining to these beliefs, to manifest oneself in your personal life according to your precepts and to be able to live according to those beliefs. This article aims to address the following concepts: - What are Fundamental Rights. As well as the incorporation of international human rights treaties. As the title itself indicates: An approach to the Collision of Fundamental Rights regarding religious freedom in Brazil, we will study what is religious freedom, its evolution as one of the first fundamental rights that arise with constitutionalism and the rights of defense, the collision of fundamental rights, the effectiveness of constitutional norms and how the jurisprudence deals with this collision regarding religious freedom in Brazil.

Keywords: Fundamental Rights, Religious Freedom, Collision of Fundamental Rights, Jurisprudence Religious Freedom in Brazil. 


\section{Introdução}

A liberdade religiosa é um dos direitos fundamentais da humanidade, como afirma a Declaração Universal dos Direitos Humanos. No entanto, muitas vezes o preconceito existe e se manifesta pela humilhação imposta àquele que é diferente.

A liberdade religiosa está relacionada ao conceito de laicidade. É importante frisar que não é necessário que um Estado seja laico para que liberdades religiosas existam nele. Entretanto, um Estado laico, como o Brasil, ao se afirmar como tal, tem o compromisso de separar Estado e religião e de proteger a liberdade religiosa, garantindo esse direito a todos os seus cidadãos. Além disso, como Estado laico, o Brasil não deve influenciar as crenças pessoais de seus cidadãos e não deve permitir que as crenças religiosas de seus governantes tenham influência direta na formulação de suas políticas.

Primeiramente a evolução dos direitos fundamentais, seu conceito e sua categorização serão tratados de forma não exaustiva, pois o objetivo do artigo é a colisão do direito fundamental de Liberdade Religiosa frente a outros direitos fundamentais. Neste aspecto, como há diversos tratados dos quais o Brasil é signatário abordamos no trabalho a incorporação dos Tratados Internacionais de Direitos Humanos.

O tema liberdade religiosa mereceu destaque na pesquisa, pois é o foco do artigo, bem como a colisão de direitos fundamentais. As jurisprudências foram inseridas no intuito de exemplificar situações as quais se relacionam, não esgotando o tema. Até por ser uma jurisprudência em construção, tendo em vista julgados que ainda estão sendo aguardados, que serão citados.

No intuito de apresentar melhor conclusão ao trabalho também é apresentado o conceito de eficácia das normas constitucionais.

\section{O que são direitos fundamentais}

Para a Dra. Regina Maria Nery Ferrari são considerados direitos fundamentais, os direitos humanos legislados, conforme o entendimento expressados em suas aulas de Direito Constitucional na Universidade Tuiuti do Paraná, que citando Robert Alexy, que tratava como relevantes os direitos fundamentais expressos na Carta Política.

Outrossim, vemos que também são relevantes, além dos direitos fundamentais legislados, devidamente garantidos, os que decorrem de alguns princípios, em destaque "dignidade da pessoa humana", princípio basilar no estudo dos Direitos Humanos 


\title{
(Fundamentais).
}

Alexy ${ }^{1}$ não nos traz um estudo específico dos direitos fundamentais, um case, e Ferrari também não se debruçou sobre o direito fundamental que nos cabe neste trabalho, o de liberdade religiosa.

Mas, temos diversos estudiosos que se debruçaram sobre o tema. José Afonso da Silva assim expressa:

“... na liberdade de crença entra a liberdade de escolha da religião, a liberdade de aderir à qualquer seita religiosa, a liberdade (ou o direito) de mudar de religião, mas também compreende a liberdade de não aderir à religião alguma, assim como a liberdade de descrença, a liberdade de ser ateu e de exprimir o agnosticismo"2

Wolfgang Sarlet nos ensina:

\begin{abstract}
"No contexto constitucional, assume relevo a circunstância de que, na condição de direitos subjetivos, as liberdades de religião e de consciência asseguram tanto a liberdade de adotar e cultivar (ou não) uma fé religiosa ou uma convicção ou ideologia, quanto geram direitos à proteção contra perturbações ou qualquer tipo de coação oriunda do Estado ou de particulares. Já como elementos fundamentais da ordem jurídico-estatal objetiva, tais liberdades fundamentam a neutralidade religiosa e ideológica do Estado, como pressuposto de um processo político livre e como base do Estado Democrático de Direito (Konrad Hesse, Grundzüge des Verfassungsrechts der Bundesrepublik Deutschland, Heidelberg: C.F. Müller, p. 167). ${ }^{3}$
\end{abstract}

\section{- Categorização dos Direitos Humanos}

No desenvolvimento da cultura dos direitos humanos temos os primeiros direitos assegurados: os direitos de liberdade, a tutela das liberdades, surgem com as primeiras declarações de direito no século XVIII, nestes a primeira geração. Nesta categoria temos os direitos em que se assegura um não fazer por parte do Estado em relação aos cidadãos, nestes estão os direitos individuais.

Com o desenvolvimento industrial, século XIX, a exploração do trabalho humano de forma diversa do que já ocorria, surge a segunda dimensão dos direitos humanos, os direitos de igualdade, expressados nos direitos sociais. ${ }^{4}$

Após a segunda guerra mundial com o desenvolvimento de anseios além das

\footnotetext{
1 ALEXY, Robert. Teoría de los derechos fundamentales. Madrid: Centro de Estudios Políticos y Constitucionales, 2001.

2 SILVA, José Afonso da. Curso de Direito Constitucional Positivo. São Paulo: Saraiva, 1995.

3 SARLET Wolfgang, Liberdade religiosa e dever de neutralidade estatal na Constituição Federal de 1988.http://www.conjur.com.br/2015-jul-10/direitos-fundamentais-liberdade-religiosa-deverneutralidade-estatal-constituicao-federal-1988 , consultado em 15 de junho de 2017.

${ }^{4}$ NOVELINO, Marcelo. Direito Constitucional. São Paulo: Editora Método, 2009, $3^{\circ}$ ed., 362/364.
} 
pessoas individuais, ou grupos de trabalhadores surgem os direitos de terceira geração, os direitos de solidariedade, fraternidade (também conhecidos como direitos difusos). Nesta categoria estão o direito ao meio ambiente direito de propriedade sobre o patrimônio comum da humanidade e ao direito de comunicação. ${ }^{5}$

Atualmente já vislumbramos nova categorização se formando, com os direitos relativos ao genoma humano, com os direitos relativos à internet, dentre outros.

\title{
- Tratados internacionais e liberdade religiosa
}

O Brasil é signatário da Declaração Universal dos Direitos Humanos, aprovada em 1948, pela Assembleia Geral das Nações Unidas. Cujas letras adiante expressas, que estão no seu artigo primeiro, nos trazem um sentimento de fé e esperança nas relações humanas: Todos os homens nascem livres e iguais em dignidade e direitos. São dotados de razão e consciência e devem agir em relação uns aos outros com espírito de fraternidade.

Esta declaração visa proteger direitos básicos a existência humana e assim expressa em seu artigo $3^{\circ}$ que "Todo indivíduo tem direito à vida, à liberdade e à segurança pessoal."

Neste artigo terceiro quando assegura o direito à liberdade já podemos compreender todos os tipos de liberdade: de pensamento, de opinião, de religião, de associação.

Mas, com o objetivo de não haver dúvidas, esta mesma, declara expressamente em seu artigo 18:

\begin{abstract}
"Artigo $18^{\circ}$ Toda a pessoa tem direito à liberdade de pensamento, de consciência e de religião; este direito implica a liberdade de mudar de religião ou de convicção, assim como a liberdade de manifestar a religião ou convicção, sozinho ou em comum, tanto em público como em privado, pelo ensino, pela prática, pelo culto e pelos ritos."
\end{abstract}

O pacto internacional sobre direitos civis e políticos (celebrado em Nova York, na data de 19 de dezembro de 1966), ratificado pelo Brasil pelo Decreto 592 de 06 de julho de 1992, em seu preâmbulo considera: "o reconhecimento da dignidade inerente a todos os membros da família humana e de seus direitos iguais e inalienáveis constitui o

$5 \quad$ http://www.stf.jus.br/portal/constituicao/constituicao.asp http://redir.stf.jus.br/paginadorpub/paginador.jsp?docTP=AC\&docID=595444 consultado em 02 de abril de 2017. 
fundamento da liberdade, da justiça e da paz no mundo". Nestes termos temos o fundamento dos direitos humanos fundamentais: "A dignidade da Pessoa Humana". Desta dignidade decorrem todos os direitos e por esta dignidade são limitados.

Também este pacto (internacional sobre direitos civis e políticos) em seu artigo 18 (coincidentemente no mesmo artigo) assegura esta liberdade religiosa e a especifica nos seguintes termos, in verbis:

1. Toda pessoa terá direito a liberdade de pensamento, de consciência e de religião. Esse direito implicará a liberdade de ter ou adotar uma religião ou uma crença de sua escolha e a liberdade de professar sua religião ou crença, individual ou coletivamente, tanto pública como privadamente, por meio do culto, da celebração de ritos, de práticas e do ensino.

2. Ninguém poderá ser submetido a medidas coercitivas que possam restringir sua liberdade de ter ou de adotar uma religião ou crença de sua escolha.

3. A liberdade de manifestar a própria religião ou crença estará sujeita apenas à limitações previstas em lei e que se façam necessárias para proteger a segurança, a ordem, a saúde ou a moral públicas ou os direitos e as liberdades das demais pessoas.

4. Os Estados Partes do presente Pacto comprometem-se a respeitar a liberdade dos países e, quando for o caso, dos tutores legais de assegurar a educação religiosa e moral dos filhos que esteja de acordo com suas próprias convicções. (grifo nosso)

No pacto internacional sobre direitos civis e políticos, na Declaração Universal dos Direitos Humanos temos os instrumentos normativos internacionais que garantem a liberdade religiosa dos indivíduos e a liberdade de formar seus filhos nos mesmos critérios: ideológico, moral, religioso. Claro que tal direito dos tutores legais será limitado conforme os filhos forem adquirindo seu discernimento e poderão optar por continuar com tal confissão religiosa, ou optar por outra, ou ainda optar por ser agnóstico. Quando será este momento poderá ser estudo de outro trabalho.

\section{Liberdade Religiosa}

Trataremos da liberdade religiosa fazendo menção a itens da dissertação "Limites a intervenção do Estado a Liberdade Religiosa de Crianças e Adolescentes Orientados pelos Pais", apresentado no $3^{\circ}$ Seminário do Núcleo Paranaense de Pesquisas em Religião, no ano de $2006 .{ }^{6}$

\footnotetext{
${ }^{6}$ Tivemos a oportunidade de participar daquele seminário, no GT1 - O SAGRADO: CONCEPÇÕES E MANIFESTAÇÕES, informações daquele seminário em: http://www.nupper.com.br/home2/?page_id=116
} 
Em análise, a sociedade ocidental depois de Cristo temos que, nos tempos mais remotos do Império, os Papas eram os responsáveis pela nomeação de imperadores, como também pela sua demissão.

Na Antiguidade, os sentimentos pagãos estavam em primeiro lugar, seguidos pelos sentimentos cristãos, quando foi moldado o Estado antigo, na época medieval. Por consequiência de existir de modo dominante no mundo ocidental, a religião católica apostólica romana nem sequer se fazia menção à liberdade religiosa.

A partir da Revolução Americana e da Declaração de Virgínia de 12 de junho de 1776 (século XVIII) é que foi mencionado pela primeira vez o tema "liberdade religiosa", e, como forma de princípios fundamentais, pregava-se a separação da Igreja do Estado, bem como o livre exercício de qualquer religião. ${ }^{7}$

Retornando aos idos do século XVI, países católicos como a França, a Espanha protegiam a todo custo seus fiéis, ao passo que seus inimigos infiéis, eram perseguidos, alguns até eram queimados vivos, e muitas vezes até massacrados todos (como ocorreu com as fogueiras da Santa Inquisição, e a Noite de São Bartolomeu).

Atualmente, podemos medir a tolerância de uma determinada sociedade, pelo modo como esta demonstra respeito ou não pela opção religiosa de suas minorias. E esta é uma das formas de afirmar seu compromisso com a harmonia religiosa.

Para Sahid Maluf, a liberdade religiosa "é um direito que não precisa de garantia jurídica, porque pertence ao foro interno do homem e não admite restrição; nem precisa proteção do estado". ${ }^{8}$ E a respeito da Constituição, afirma que esta "distingue e separa liberdade de pensamento e liberdade de manifestação de crença". Sendo que somente a manifestação, ou seja, "a exteriorização do pensamento, da consciência, da crença, é suscetível de limitações pelo poder estatal". 9

\section{- Delimitação terminológica}

Rubem A. Alves, em seu livro “O que é religião?”, afirma que “é fácil identificar, isolar, e estudar a religião como o comportamento exótico de grupos sociais restritos e distantes.

\footnotetext{
${ }^{7}$ MELlO FILHO, José Celso. Constituição... Op. Cit. p. 440. In: MORAES, Alexandre de. Direito Constitucional. p. 68

${ }^{8}$ MALUF, Sahid. In: GODOY, Arnaldo Moraes. A Liberdade Religiosa nas Constituições do Brasil. São Paulo: Editora Revista dos Tribunais, 2001. p. 158.

${ }^{9}$ MALUF, Sahid. In: GODOY, Arnaldo Moraes. A Liberdade Religiosa nas Constituições do Brasil. São Paulo: Editora Revista dos Tribunais, 2001. p. 158.
} 
Mas é necessário reconhecê-la como presença invisível, sutil, disfarçada, que se constitui num dos fios com que se tece o acontecer do nosso cotidiano. A religião está mais próxima da nossa experiência pessoal do que desejamos admitir. O estudo da religião, portanto, longe de ser uma janela que se abre apenas para panoramas externos, é como um espelho em que nos vemos". ${ }^{10}$

A definição para a palavra religião, segundo o Novo Dicionário Aurélio é a seguinte: "Religião, (do lat. Religione) s.f. 1. Crença na existência de uma força ou forças sobrenaturais, considerada(s) como criadora(s) do Universo, e que como tal deve(m) ser adorada(s) e obedecida(s); 2. A manifestação de tal crença por meio de doutrina e ritual próprios, que envolvem, em geral, preceitos éticos; 3. Restrita virtude do homem que presta a Deus o culto que lhe é devido; 4. Reverência às coisas sagradas; 5. Crença fervorosa; devoção, piedade; 6. Crença numa religião (v. religião 1 e 2) determinada, fé, culto; 7. Vida religiosa; 8. Qualquer filiação a um sistema específico de pensamento ou crença que envolve uma posição filosófica, ética, metafísica, etc. 9. Modo de pensar ou de agir; princípios". E de acordo com o mesmo dicionário, podemos mencionar a definição de Seita, “(do lat. Secta) s.f. 1. Doutrina ou sistema que diverge da opinião geral e é seguido por muitos; 2 . Conjunto de indivíduos que professam a mesma doutrina; 3. Comunidade fechada de cunho radical; 4. Teoria de um mestre seguida por numerosos prosélitos; 5. Pop. Facção, partido". ${ }^{11}$

Quando falamos em liberdade religiosa, seguramente estamos incluindo toda a liberdade de corpo (que caracteriza o ir e vir dos indivíduos) bem como a liberdade de opinião (que é o poder de escolha inerente a cada um), e o culto, liturgia e crença devem ser protegidos em seu nome.

Já sob o ponto de vista de alguns constitucionalistas, podemos citar Celso Bastos ${ }^{12}$, que afirma que "a liberdade de consciência não se confunde com a liberdade de crença", pois a liberdade de crença inclui a opção de não ter crença (como no caso ateus e agnósticos). Outrossim, explicamos que pode haver liberdade de crença sem liberdade de culto, mas no caso de haver liberdade religiosa, haverá liberdade de culto e de crença.

Ao citarmos José Afonso da Silva, devemos ressaltar sua visão a respeito de liberdade

\footnotetext{
${ }^{10}$ ALVES, Rubem A. O que é religião? p. 12

${ }^{11}$ FERREIRA, Aurélio Buarque de Holanda. Novo Dicionário Aurélio.

${ }^{12}$ BASTOS, Celso. Curso de Direito Constitucional. São Paulo: Saraiva, 1990. p. 114 et seq In: GODOY, Arnaldo Moraes. A Liberdade Religiosa nas Constituições do Brasil. São Paulo: Editora Revista dos Tribunais, 2001. p. 157.
} 
religiosa, que segundo ele "inclui a liberdade religiosa entre as liberdades espirituais, e que estas compreendem a liberdade de crença, culto e de organização social". ${ }^{13}$

- Liberdade de crença

Mesmo no primeiro reinado havia a liberdade de crença, apenas os cultos deveriam se realizar a portas fechadas, somente sendo os cultos católicos admitidos com as portas abertas.

Segundo Scampini ${ }^{14}$ : "O princípio da liberdade de crença e consciência estava implicitamente reconhecido pela Constituição do Império, art. 79, e explicitamente pela Republicana de 1891, no art. 72, inciso 28".No entanto, o Anteprojeto apresentado pela Comissão Constitucional, declarava em seu art. 106 que "é inviolável a liberdade de consciência e de crença". Com isso, liberdade de consciência e de crença não foi alterada em seu texto, e ainda teve votação como texto básico do Título Religião.

"É inviolável a liberdade de consciência e crença, e assegurando o livre exercício dos cultos religiosos, salvo o dos que contrariem a ordem pública e os bons costumes".

No texto constitucional de 1946, faz-se menção às liberdades seguindo a linha constitucional de 1934, onde de acordo com o dispositivo constitucional, têm-se teoricamente um desdobramento em três partes do tema de liberdade religiosa, sendo estas a de consciência, crença e culto. ${ }^{15}$

A liberdade de crença, para José Afonso da Silva, envolve muitas liberdades, entre elas a "liberdade de escolha de religião, de adesão a qualquer seita religiosa, de poder mudar de religião, podendo ser ateu, não se identificando com religião nenhuma, e até exprimir o agnosticismo". ${ }^{16}$

Desta forma, afirma J. Cretella Jr, a "consciência é sempre livre", e que "a liberdade de consciência não necessita de proteção constitucional ou legal", "o direito não se preocupa com os atos internos ou intransitivos do homem, que, aliás, não perturbam nenhuma pessoa, nem a ordem jurídica". Para ele, "a liberdade de consciência comporta

\footnotetext{
${ }^{13}$ SILVA, José Afonso da. Curso de Direito Constitucional Positivo. São Paulo: Saraiva, 1995. p. 241 et seq. In: GODOY, Arnaldo Moraes. A Liberdade Religiosa nas Constituições do Brasil. São Paulo: Editora Revista dos Tribunais, 2001. p. 157

14 SCAMPINI, Pe. José . A Liberdade Religiosa nas Constituições Brasileiras. Petrópolis: Vozes, 1978. p. 156-157.

15 SCAMPINI, Pe. José . A Liberdade Religiosa nas Constituições Brasileiras. p. 214

16 SILVA, José Afonso da. Curso de Direito Constitucional Positivo, 1995, p. 241. In: GODOY, Arnaldo Moraes. A Liberdade Religiosa nas Constituições do Brasil. São Paulo: Editora Revista dos Tribunais, 2001. p. 157
} 
o direito de crer no que se deseja e de filiar-se à religião preferida, como também o direito de não professar religião alguma". E ressalta, ainda que, este direito não implica, no entanto, "a livre prática dos cultos". E afirma ainda que a "liberdade de culto e liberdade de crença são duas coisas distintas". E para ele, ainda, "a consciência é a liberdade de opinião, concentrada na fé, na crença ou qualquer aspecto da vida do ser humano". Então: "consciência é a fé interiorizada", e "religião ou culto é a fé exteriorizada". ${ }^{17}$

\section{- Liberdade de culto}

A base de toda a virtude social e também o fundamento de toda a moral são os princípios que regem a Justiça. Todo cidadão possui como primeiro e mais íntimo de todos os seus deveres, a retribuição ao seu criador, e esta se confirma como a lei suprema de todos os seres. E segundo o Pe. José Scampini, "a observância desse dever e o desenvolvimento desse princípio, mais ou menos aparente, constitui o culto interno e externo". ${ }^{18}$

É necessário estabelecer a diferença entre o culto interno e o externo. O primeiro é a representação da fé, do amor, da adoração espiritual, e caracteriza-se por ser uma relação direta com o Ser Supremo. E este é um dos direitos mais invioláveis da pessoa humana. J. Cretella Jr. ressalta nesse sentido, que "a liberdade de culto diz respeito às manifestações ligadas à religião que se tem". Desta forma, "a liberdade de culto sofre restrições impostas pela lei e pelos regulamentos de polícia”. E no campo jurídico, ainda com as palavras de J. Cretella Jr., "culto é o conjunto de práticas religiosas destinadas ao aperfeiçoamento dos sentidos humanos". ${ }^{19}$

O culto é externo quando ocorre uma manifestação pública do pensamento do indivíduo, relativo à sua crença, sob forma de ritos, cerimônias, ou até mesmo preces. Neste momento, ele deixa de ser tratado como "liberdade de consciência" e passa a ser considerado "liberdade de culto", e sempre em defesa da ordem pública, pode chegar a permitir uma intervenção do legítimo poder social.

No que se refere ao tema da liberdade de culto, a Emenda de 1969 definia: "É plena a liberdade de consciência e fica assegurado aos crentes o exercício dos cultos religiosos, que não contrariem a ordem pública e os bons costumes", sendo que a de 1934

17 Cretella Júnior, José. Comentários à Constituição de 1988, p. 216. In: Exercício da Liberdade Religiosa. Maria Luiza Whately Barretto. p. 250 18 SCAMPINI, Pe. José. A Liberdade Religiosa nas Constituições Brasileiras. p. 200

19 Cretella Júnior, José. Comentários à Constituição de 1988, p. 216. In: Exercício da Liberdade Religiosa. BARRETO, Maria Luiza Whately. p. 250. 
e a de 1946 garantiam "o livre exercício dos cultos religiosos". Sendo que a de 1891 e a de 1937 possuíam formulação semelhante, onde "todos os indivíduos e confissões religiosas podem exercer pública e livremente seu culto". ${ }^{20}$

A definição para a liberdade de culto sob a ótica de José Afonso da Silva pode ser entendida como a "liberdade de orar, de praticar atos próprios das manifestações exteriores (em casa ou em público), bem como a liberdade de receber contribuições para tais fins". 21

Segundo o art. 208 do Código Penal, constitui crime, sujeitando o seu responsável à pena de detenção, de um mês até um ano, ou multa, as seguintes práticas: a) escarnecer de alguém publicamente por motivo de crença ou função religiosa; b) impedir ou perturbar cerimônia ou prática de culto religioso; c) vilipendiar publicamente ato ou objeto de culto religioso. ${ }^{22}$

\section{- Liberdade de organização religiosa}

Na Constituição de 1891, está expresso, no que se refere à liberdade de associação religiosa, que "todos os indivíduos e confissões religiosas podem exercer pública e livremente o seu culto, associando-se para este fim e adquirindo bens, observadas as disposições do direito comum". ${ }^{23}$

No que se refere ao tema das associações religiosas, é relevante ressaltar que na Constituição de 1934, na segunda parte do parágrafo $5^{\circ}$ do art. 113 é feita uma alteração considerável ao criar personalidade jurídica com relação aos termos da lei civil.

Na Constituição de 1937, temos que "Todos os indivíduos e confissões religiosas podem exercer pública e livremente seu culto, associando-se para esse fim e adquirindo bens, observadas as disposições do direito comum".

Na Constituição de 1967, bem como após a instituição da Emenda de 1969, é garantida a liberdade de consciência plena, diferente das Constituições de 34 e 46, onde era considerada inviolável, e mais ainda, difere da de 37 e 91 que nem ao menos faziam referência à liberdade de consciência.

A emenda de 1969, no que diz respeito à liberdade religiosa, expressava da

20 SCAMPINI, Pe. José. A Liberdade Religiosa nas Constituições Brasileiras. p. 236.

21 SILVA, José Afonso da. Curso de Direito Constitucional Positivo. São Paulo: Saraiva, 1995. p. 241 et seq In: GODOY, Arnaldo Moraes. A Liberdade Religiosa nas Constituições do Brasil. São Paulo: Editora Revista dos Tribunais, 2001. p. 158.

22. DOTTI, René Ariel. Declaração Universal dos Direitos do Homem e Notas da Legislação Brasileira. p. 39

23 SCAMPINI, Pe. José . A Liberdade Religiosa nas Constituições Brasileiras. p. 108. 
seguinte maneira o tema: “À União, aos Estados, ao Distrito Federal e aos Municípios é vedado: estabelecer cultos religiosos ou igrejas subvencioná-los, embaraçar-lhes o exercício ou manter com eles ou seus representantes relações de dependência ou aliança, ressalvada a colaboração de interesse público, na forma e nos limites da lei federal, notadamente no setor educacional, no assistencial e no hospitalar". ${ }^{24}$

\section{- Constituição de 1988 e Direitos Fundamentais}

Face o regime de exceção que precedeu a elaboração de nossa Carta Política de 1988, os direitos e garantias individuais que na Carta de 1967 encontravam-se no artigo 150 e poderiam ser suspensos (artigo 151, Carta de 1967) passaram a integrar o início de nossa constituição cidadã, logo no artigo quinto.

Nos primeiros quatro artigos temos o como se constitui o estado brasileiro (União, Estados, DF, Municípios), seus poderes (Legislativo, Executivo e Judiciário), seus objetivos e finalmente seus princípios nas relações internacionais.

Esta priorização dos direitos individuais está destacada ainda, como limitador do poder constituinte derivado, onde no art. $60 \S 4^{\circ}$, inciso IV, in verbis:

Art. 60. A Constituição poderá ser emendada mediante proposta: $\S 4^{\circ}$ Não será objeto de deliberação a proposta de emenda tendente a abolir:

I - a forma federativa de Estado;

II - o voto direto, secreto, universal e periódico;

III - a separação dos Poderes;

IV - os direitos e garantias individuais.

Desta forma além de estarem assegurados na Constituição, não é possível por uma emenda constitucional a exclusão, ou mesmo a diminuição dos mesmos.

\section{- Liberdade religiosa na Constituição de 1988}

VI - é inviolável a liberdade de consciência e de crença, sendo assegurado o livre exercício dos cultos religiosos e garantida, na forma da lei, a proteção aos locais de culto e a suas liturgias;

VII - é assegurada, nos termos da lei, a prestação de assistência religiosa nas entidades civis e militares de internação coletiva;

VIII - ninguém será privado de direitos por motivo de crença religiosa ou de convicção filosófica ou política, salvo se as invocar para eximir-se de obrigação legal a todos imposta e recusar-se a cumprir prestação alternativa,

24 SCAMPINI, Pe. José. A Liberdade Religiosa nas Constituições Brasileiras. p. 234. 
fixada em lei;

A Constituição de 1988 amplia texto que vem desde a Carta Política de 1946: ${ }^{25}$

Art. 19. É vedado à União, aos Estados, ao Distrito Federal e aos Municípios: I - estabelecer cultos religiosos ou igrejas, subvencioná-los, embaraçar-lhes o funcionamento ou manter com eles ou seus representantes relações de dependência ou aliança, ressalvada, na forma da lei, a colaboração de interesse público;

A constituição de 1988 assegura a liberdade religiosa na sua totalidade: a liberdade de crença, de culto e de organização religiosa.

\section{- Direitos fundamentais e tratados internacionais}

A Constituição de 1988 assegura, além dos direitos fundamentais expressos nela, os direitos em que a República Federativa do Brasil se comprometeu na comunidade internacional pela celebração de tratados.

Então, vamos a Constituição para ver de que forma é realizada esta incorporação dos tratados internacionais no ordenamento interno brasileiro

\footnotetext{
$\S 2^{\circ}$ Os direitos e garantias expressos nesta Constituição não excluem outros decorrentes do regime e dos princípios por ela adotados, ou dos tratados internacionais em que a República Federativa do Brasil seja parte.

$\S 3^{\circ}$ Os tratados e convenções internacionais sobre direitos humanos que forem aprovados, em cada Casa do Congresso Nacional, em dois turnos, por três quintos dos votos dos respectivos membros, serão equivalentes às emendas constitucionais.
}

A inclusão do acima citado parágrafo $3^{\circ}$ do artigo $5^{\circ}$, com a emenda constitucional, 45 do ano de 2004, nas palavras do ministro Gilmar Mendes em seu voto no RE no 466.343: "acabou por ressaltar o caráter especial dos tratados de direitos humanos em relação aos demais tratados de reciprocidade entre os Estados pactuantes, conferindo-lhes lugar privilegiado no ordenamento jurídico".

Para fins de explicitar a incorporação dos tratados internacionais de direitos humanos, embora este estudo seja a respeito da liberdade religiosa, trataremos do lide in case que dizia respeito à prisão civil do depositário infiel, prevista no artigo $5^{\circ}$, LXVII da Constituição de 1988:

25 Em 1946 o texto era: “À União, aos Estados e ao Distrito Federal e aos Ministros é vedado: Il estabelecer ou subvencionar cultos religiosos ou embaraçar-lhes o exercício; III ter relação de aliança ou dependência com qualquer culto ou igreja, sem prejuízo da colaboração em prol do interesse coletivo" 
LXVII - não haverá prisão civil por dívida, salvo a do responsável pelo inadimplemento voluntário e inescusável de obrigação alimentícia e a do depositário infiel;

Em contraste com o artigo 7.7 da Convenção Americana sobre Direitos Humanos (CADH): que dispõe que "Ninguém deve ser detido por dívidas. Este princípio não limita os mandados de autoridade judiciária competente expedidos em virtude de inadimplemento de obrigação alimentar."

De princípio, o STF continuou aplicando o contido na Carta de 1988, considerando que a ratificação da $\mathrm{CADH}$, em 1992, pelo Brasil, não havia afetado o seu conteúdo. Considerando os tratados internacionais como legislação ordinária, porém em 2008 mudou seu entendimento, assim manifestando-se sobre a possibilidade da prisão do depositário infiel:

(...) desde a adesão do Brasil, sem qualquer reserva, ao Pacto Internacional dos Direitos Civis e Políticos (art. 11) e à Convenção Americana sobre Direitos Humanos - Pacto de San José da Costa Rica (art. $7^{\circ}, 7$ ), ambos no ano de 1992, não há mais base legal para prisão civil do depositário infiel, pois o caráter especial desses diplomas internacionais sobre direitos humanos lhes reserva lugar específico no ordenamento jurídico, estando abaixo da Constituição, porém acima da legislação interna. O status normativo supralegal dos tratados internacionais de direitos humanos subscritos pelo Brasil, dessa forma, torna inaplicável a legislação infraconstitucional com ele conflitante, seja ela anterior ou posterior ao ato de adesão. Assim ocorreu com o art. 1.287 do CC de 1916 e com o DL 911/1969, assim como em relação ao art. 652 do novo CC (Lei 10.406/2002).

[RE 466.343, rel. min. Cezar Peluso, voto do min. Gilmar Mendes, j. 3-122008, P, DJE de 5-6-2009, com repercussão geral. $]^{[5]}$

Entendimento que foi expressando na súmula vinculante 25 (STF) "É ilícita a prisão civil de depositário infiel, qualquer que seja a modalidade de depósito."

Neste diapasão temos a incorporação dos Tratados Internacionais em Direitos Humanos como uma categoria legislativa diferenciada. Podem atualmente serem incorporados como emenda à constituição nos termos do parágrafo $3^{\circ}$ do artigo $5^{\circ}$, ou se incorporados anteriormente à promulgação da emenda constitucional 45 de 2004, serão considerados em lugar privilegiado no ordenamento jurídico.

\section{Colisão de Direitos fundamentais concernentes à liberdade religiosa}

Faz-se necessário relembrar que os direitos fundamentais surgem como direitos 
de defesa do cidadão em face do Estado, que no século XVIII era absolutista com poder de vida e de morte em relação aos súditos.

O constitucionalismo (do século XVIII) surge como um limitador aos poderes do monarca e os direitos fundamentais naquele momento vem na mesma esteira. Seria a eficácia vertical dos direitos fundamentais, ou seja, o estado em relação aos cidadãos.

Quando tratamos de colisão de direitos fundamentais nosso ponto é outro é a eficácia horizontal, entre os diversos direitos, de que forma os exercitamos em relação aos outros cidadãos, a antiga frase: Meu direito vai até onde inicia o direito do outro.

Quando tratamos de colisão de direitos de outra natureza (não os fundamentais) há três maneiras de se dissipar a antinomia: cronologia, hierarquia e especialidade das leis. ${ }^{26}$

Porém, quando tratamos de direitos fundamentais não podemos aplicar a cronologia, quando há contemporaneidade das normas, por exemplo, as contidas na Carta Política.

Nem a hierarquia, pois em termos de direitos fundamentais consideram-se princípios, e como já dito que consagram a dignidade da pessoa humana.

Assim exorta Farias: "não se resolve a colisão entre dois princípios suprimindose um em favor do outro. A colisão é solucionada levando-se em conta o peso ou a importância relativa de cada princípio, a fim de escolher qual deles no caso concreto prevalecerá ou sofrerá menos constrição do que o outro." [28]

A presença de conteúdo aberto que por vezes só se revela no caso concreto torna freqüente a colisão de direitos fundamentais. Que somente podem ser analisados frente ao caso concreto.

Jurisprudência quanto à colisão de direitos fundamentais relativamente a liberdade religiosa

Entendemos que qualquer direito fundamental não pode ser considerado como absoluto, visto que, pode haver a necessidade de limitação de um Direito Fundamental, para que se garanta o exercício de outro (Direito Fundamental).

\section{- Liberdade de culto e direito à intimidade e ao silêncio}

26 BOBBIO, Norberto. Teoria do Ordenamento Jurídico. 10. ed. (tradução de Maria Celeste C. J. Santos). Brasília: Editora Universidade de Brasília, 1997 
Como exemplo de demanda em relação ao direito constitucional, podemos citar a Jurisprudência Comentada (AASP 1.756 a 25.08.1992, p. 297), para melhor leitura, embora seja citação, manteremos a largura integral da linha.

No caso em questão, "a Igreja Universal do Reino de Deus impetrou Mandado de Segurança contra ato do Sr. P.M.D., alegando violação de Direito Constitucional, devido ao fechamento do templo onde se realizavam as práticas religiosas da seita. A liminar foi concedida, foram prestadas as informações, segundo as quais o ato investiu-se de toda a legalidade, demonstrando que a impetrante não atendeu à exigências das autoridades. $\mathrm{O}$ Mandado foi julgado improcedente, e a sentença denegou a segurança. A impetrante apelou, alegando a existência de possibilidade - como vimos acima - para exercitar a liberdade religiosa fora dos templos. Negou-se provimento ao recurso". Segundo Maria Luiza Wathely Barreto, que comenta o caso, "a referida decisão encontrava-se embasada de fundamentos, pois a apelante várias vezes foi notificada para regularizar sua situação; não tomando conhecimento de tais notificações, preferiu desrespeitar normas municipais e direitos alheios (direitos de seus vizinhos). Assim quando se viu envolta por problemas que ela mesma criou, tentou solucioná-los mediantes o disposto no art. $5^{\circ}$ de nossa constituição, que garante o exercício da liberdade religiosa"[29].

Como se pode perceber, a decisão está claramente baseada nos fundamentos, pois como está claro nos autos deste processo, a apelante foi notificada diversas vezes, para que buscasse uma solução, e simplesmente nada fez. Continuou a desrespeitar além de direitos de seus vizinhos, normas municipais, e após o fechamento do templo, tentou através do dispositivo do art. $5^{\circ}$ da nossa Constituição, garantir o exercício de seu direito à liberdade religiosa.

No entanto como afirma Maria Luiza, "referida garantia não inibe o exercício da autoridade de polícia administrativa, posto que a apelante estava prejudicando o sossego alheio, isto é, dos moradores vizinhos que se viam obrigados a ouvir o que lhes transmitia a sua aparelhagem de som em proporções desmedidas". E ainda acrescenta, que "desta forma, a apelante desrespeitou direitos fundamentais de seus vizinhos, sendo eles: o direito à intimidade (art. $5^{\circ}, \mathrm{X}$, da Constituição Federal ), e a própria liberdade de consciência e de crença (art. $5^{\circ}$, VI, da Constituição Federal), da qual reclamava a apelante estar sendo privada".

É necessário mencionarmos que a liberdade de consciência e exercício pleno da 
prática religiosa só pode sofrer restrição do Poder Público, se as pregações, cultos ou cânticos contrariem a ordem pública, bem como o sossego e a tranqüilidade. Deste modo, é lícito ao Município proibir tal prática em zona residencial da cidade, sendo que a sentença é a seguinte: "VIOLAÇÃO DE DIREITO CONSTITUCIONAL - Exercício da liberdade religiosa - fechamento feito com observância da lei. A liberdade religiosa garantida em nossa Constituição, não permite desrespeito ao direito de repouso da coletividade e afrontar as autoridades municipais. (TJSP - $1^{\circ}$ Câm. Cível; Ap. Cível 146.692 - 1/6 - Diadema; rel. Des. Andrade Marques; j. 01.10.1991; v.u.)".[78]

Então, no caso acima se entendeu que o direito à liberdade religiosa foi relativizado pelo direito ao silêncio dos moradores vizinhos ao templo, que ampliava sua pregação com alto falantes nas ruas de bairro residencial. Neste caso podemos também ver a colisão com a própria liberdade religiosa dos moradores, que ao que nos faz crer, professavam outra fé.

Destacando que quanto ao poder público não tomou uma decisão imediata, após as reclamações. Pelo contrário, existiram diversas notificações à entidade religiosa e aquela desrespeitou os direitos dos vizinhos, as normas de direito municipal. Não buscou uma conciliação, nem atendeu as notificações. Somente vindo a argüir o direito à liberdade religiosa em juízo.

\title{
- Liberdade religiosa e o direito a vida de incapaz
}

\author{
VOTO-VISTA, do SR. MINISTRO LUIZ VICENTE CERNICCHIARO, RECURSO EM \\ HABEAS CORPUS N $7.785-\mathrm{SP}[30]$
}

“O SR. MINISTRO LUIZ VICENTE CERNICCHIARO: O tema posto neste julgamento implica incursionar na Teoria Geral do Direito, não obstante, aparentemente, restringir-se ao disposto no art. 146, § $3^{\circ}$, I, ou seja, "não se compreendem na disposição deste artigo - 'a intervenção médica ou cirúrgica, sem o consentimento do paciente ou de seu representante legal, se justificada por iminente perigo de vida'."

Sabe-se, "Testemunha de Jeová", considerando a natureza sagrada do sangue, não permite aos seus adeptos submeterem-se à transfusão. E mais. Recomendam manifestar expressamente essa orientação, o que, comumente, é registrada no documento de identificação. Há, pois, movimento nesse sentido. Registre-se, de âmbito internacional, com sérios e profundos estudos. Entre nós, dentre outros, mencionem-se os doutos pareceres dos conceituados Professores Manuel Ferreira Filho e Paulo Sérgio Leite Fernandes, sustentando a legalidade da recusa. Em Brasília, registre-se o abnegado trabalho do Doutor Pedro de Assis, advogado; durante vários anos, honrou e conferiu prestígio ao Ministério Público do Distrito Federal e Territórios.

O Direito, como sistema, é unidade. As normas formalizadas colocam-se em relação de coordenação e subordinação. No topo da pirâmide, para repetir o nomen iuris de Kelsen, situa-se a Constituição. Em nosso país, por sua 
característica política - Federação - a Constituição da República.

O Estado brasileiro é laico. Ao contrário da Constituição de 1824 não tem religião oficial. Daí, o disposto no art. $5^{\circ}$, VI - "é inviolável a liberdade de consciência e de crença, sendo assegurado o livre exercício dos cultos religiosos e garantida, na forma da lei, a proteção aos locais de culto e a suas liturgias". E no inciso VIII - "ninguém será privado de direito por motivo de crença religiosa ou de convicção filosófica ou política, salvo se as invocar para eximir-se de obrigação legal a todos imposta e recusar-se a cumprir prestação alternativa, fixadas em lei".

No Brasil, como em toda sociedade, há pluralidade de sistemas jurídicos. Chamar-se-á "oficial" o emanado do Estado; convive, soberanamente, e ao lado de inúmeros outros ordenamentos. Exemplo: Direito Canônico, Direito Maçônico, Direito de Testemunhas de Jeová; Direito de Associações esportivas, culturais, filantrópicas e profissionais. A relação é meramente exemplificativa.

Pois bem. Convivência significa harmonia, coordenação. O católico, o protestante professam livremente os seus cultos. Todavia, subordinados ao Direito do Estado Brasileiro. Ou seja, eventual conflito, prevalece o último. As condições para o casamento variam segundo o Direito Brasileiro e o Direito Canônico. A validade do ato num e no outro setor reclama obediência ao respectivo sistema. Há alguns anos, jovem católica, concordou com o noivo celebrar o matrimônio na Igreja Protestante, com a contrapartida de orientar os filhos na religião católica. Nascido o primeiro filho, o casal o levou para o batismo na igreja da mãe. Realizada a solenidade, ao receber o certificado, o pai ficou revoltado porque o documento mencionava - filho ilegítimo. A objeção, embora humanamente compreensível, do ponto de vista jurídico, não se justificava. Houve casamento segundo as leis do Estado brasileiro; não ocorrera, entretanto, consoante a igreja católica. Logicamente, as consequiências têm que ser diversas. A excomunhão é grave sanção canônica, sem, entretanto, nenhum efeito no direito do Estado. O suicida é tratado diferentemente no Direito Canônico e no Direito Brasileiro.

A pluralidade de sistemas, é lógico, conduz a conseqüências diversas.

Esta realidade normativa precisa estar presente, como premissa para a solução do tema sub judice.

No Direito nacional, o sangue é tido como substância essencial à vida do homem e de alguns animais; poderá ser objeto material do crime de lesão corporal (art. 129), necessário que é à saúde.

Os adeptos de Testemunhas de Jeová, ao contrário, além da realidade e características físicas, conferem-lhe natureza sacra e, por isso, intocável, impossível, então, como conseqüência, a prática de transfusão.

O Direito Penal Brasileiro volta-se para um quadro valorativo. Nesse contexto, oferece particular importância à vida (bem jurídico). Daí, por ser indisponível (o homem não pode dispor da vida). A irrelevância penal do suicídio decorre de política criminal, a fim de a pessoa que tentou contra a própria vida ser estimulada a mudar de idéia, o que provocaria efeito contrário se instaurado inquérito policial, processo e, depois, condenação, cumprimento da pena.

Em decorrência, não configura constrangimento ilegal (compelir, mediante violência, ou grave ameaça, a fazer, ou deixar de fazer alguma coisa a que não está obrigada por lei) médico, para salvar a vida do paciente, de perigo iminente, promover a transfusão de sangue, se cientificamente recomendada para esse fim.

O profissional da medicina (em qualquer especialidade) está submetido ao Direito brasileiro. Tanto assim, as normas da deontologia médica devem ajustar - se a ele. Daí, não obstante, ser adepto de Testemunha de Jeová, antes de tudo, deve cumprir a legislação vigente no país. Comparativamente, seria o mesmo o Juiz de Paz (agente do Estado), porque católico, recusar a celebração de casamento porque um dos nubentes é divorciado, o que é proibido pelo Direito Canônico. Hoje, tal pessoa pode, consoante as leis brasileiras, celebrar 
novo matrimônio.

Quanto a jurisprudência acima temos que embora prossiga a discussão a jurisprudência é pacífica no sentido de havendo colisão entre o direito de liberdade religiosa e o direito à vida, prevalece o direito à vida. Pois, sem a vida nenhum outro direito se realiza. Porém, aos adeptos de tal doutrina, com a transfusão ganharia a vida terrestre, mas perder-se-ia a vida eterna, então se pode compreender a recusa em se aceitar o sangue alheio, que segundo a doutrina dos Testemunhas de Jeová é a própria alma.

Com o objetivo de solucionar esta questão a medicina tem estudado alternativas, os adeptos da doutrina mantêm informações a respeito em Alternativa à Transfusão de sangue. ${ }^{27}$

\section{- Estado laico, defesa da fé cristã, lei municipal}

$\mathrm{Na}$ arguição de descumprimento de preceito fundamental abaixo, com pedido de liminar, ajuizada pelo Procurador-Geral da República, tendo por objeto a Lei $\mathrm{n}^{\circ} 1.515$, de 30 de junho de 2015, do Município de Novo Gama, que proíbe qualquer tipo de manifestação pública que fira ou afronte a fé cristã no Município do Novo Gama - GO o ministro Dias Toffoli faz uma bela análise do tema em sua decisão. O voto cita a decisão da ADPF 54, que permitiu o aborto de fetos anencéfalos integra a fundamentação da decisão abaixo.

Embora a representação dada ao caso foi pela violação ao sistema federativo, a competência da União em legislar sobre direito penal, á liberdade de consciência e de crença, à liberdade de expressão, a laicidade do estado e ao princípio da isonomia a decisão traz fundamentos amplos da evolução da separação igreja Estado, desde os primórdios da república brasileira. Integra a decisão as palavras do min. Marco Aurélio na ADPF 54/DF: “o Estado não é religioso, tampouco é ateu. O Estado é simplesmente neutro. (...) Se, de um lado, a Constituição, ao consagrar a laicidade, impede que o Estado intervenha em assuntos religiosos, seja como árbitro, seja como censor, seja como defensor, de outro, a garantia do Estado laico obsta que dogmas da fé determinem o conteúdo de atos estatais."

\footnotetext{
${ }^{27}$ http://testemunhas.wikia.com/wiki/Alternativa_\%C3\%A0_Transfus\%C3\%A30_de_sangue, consultado em 09 de setembro de 2017.
} 
Decisão: Vistos. Eis o teor do diploma impugnado: “Art. $1^{\circ}$ Fica proibido no Município do Novo Gama - GO qualquer tipo de manifestação pública que fira ou afronte a fé cristã. Art. $2^{\circ}$ Qualquer movimento ou manifestação pública que fira ou afronte o Cristianismo no município de Novo Gama - GO deverá ser interrompida imediatamente pelas autoridades locais. Art. $3^{\circ}$ Os envolvidos nos atos de discriminação ao Cristianismo deverão ser punidos conforme prediz o artigo 208 do Código Penal Brasileiro. Art. $5^{\circ}$ Esta Lei entra em vigor na data de sua publicação. Art. $6^{\circ}$ Revogam-se as disposições em contrário". $\mathrm{O}$ requerente sustenta violação ao princípio federativo (art. 10, caput); à competência da União para legislar sobre Direito Penal (art. 22, inciso I); à liberdade de consciência e de crença (art. $5^{\circ}$, inciso VI); à liberdade de expressão (art. $5^{\circ}$, inciso IX); à laicidade do estado (art. 19, inciso I); e ao princípio da isonomia (art. $5^{\circ}$, caput, todos da Constituição Federal). No mérito, alega que a lei municipal questionada, "ao pretender blindar o cristianismo de toda crítica (pois qualquer uma pode, segundo o critério enormemente elástico da norma, feri-lo ou afrontá-lo), hierarquiza as religiões, com o que viola a laicidade estatal". Aduz, outrossim, que a norma viola o princípio da isonomia, em síntese, por "pretender criar proteção jurídica em favor de apenas uma expressão religiosa, cristianismo".

pressamente combatidas nestes autos: a primeira, a proibição à realizaç̃̃o de manifestações públicas contra o cristianismo (art. $1^{\circ}$ ); a segunda, a determinação de interrupção imediata pelas autoridades locais, de qualquer movimento ou manifestação contra o cristianismo (art. $2^{\circ}$ ); e a terceira, a criminalização, genérica, da conduta de "discriminação ao cristianismo" (art. $3^{\circ}$ ). É assente de dúvidas a existência de vasta proteção constitucional à liberdade de crença no direito brasileiro. De fato, desde a primeira constituição da República brasileira se teve consagrada a laicidade do Estado, com reprodução expressa de preceito nesse sentido em todos os seguintes textos constitucionais. Em verdade, a proteção ao tema é mesmo anterior a sua consagração na Constituição de 1891, uma vez que, já em 7 de janeiro de 1980, o Marechal Manoel Deodoro da Fonseca, no exercício do governo provisório, proibiu, por meio do Decreto n 119 -A, "a intervenção da autoridade federal e dos Estados federados em matéria religiosa" e consagrou a plena liberdade de cultos. A norma é rica em conteúdo jurídico, sendo oportuno transcrevê-la, não apenas por traduzir a origem da legislação nacional sobre laicidade estatal, mas também pela assertividade ao instituir a liberdade religiosa. Eis o teor da norma: "O Marechal Manoel Deodoro da Fonseca, Chefe do Governo Provisorio da Republica dos Estados Unidos do Brazil, constituido pelo Exercito e Armada, em nome da Nação, decreta: Art. 1..$^{\circ}$ É prohibido à autoridade federal, assim como à dos Estados federados, expedir leis, regulamentos, ou actos administrativos, estabelecendo alguma religião, ou vedando-a, e crear diferenças entre os habitantes do paiz, ou nos serviços sustentados à custa do orçamento, por motivo de crenças, ou opiniões philosophicas ou religiosas. Art. $2 .^{\circ} \mathrm{A}$ todas as confissões religiosas pertence por igual a faculdade de exercerem o seu culto, regerem-se segundo a sua fé e não serem contrariadas nos actos particulares ou publicos, que interessem o exercicio deste decreto. Art. 3. ${ }^{\circ}$ A Liberdade aqui instituida abrange não só os individuos nos actos individuaes, sinão tambem as igrejas, associações e institutos em que se acharem agremiados; cabendo a todos o pleno direito de se constituirem e viverem collectivamente, segundo o seu credo e a sua disciplina, sem intervenção do poder publico. Art. $4^{\circ}$ Fica extincto o padroado com todas as suas instituições recursos e prerogativas. Art. $5^{\circ} \mathrm{A}$ todas as igrejas e confissões religiosas se reconhece a personalidade juridica, para adquirirem bens e os administrarem, sob os limites postos pelas leis concernentes à propriedade de mão-morta, mantendo-se a cada uma o domínio de seus haveres actuaes, bem como dos seus edificios de culto. Art. $6^{\circ} \mathrm{O}$ Governo Federal 
continua a prover à congrua, sustentação dos actuaes serventuarios do culto catholico e subvencionará por um anno as cadeiras dos seminarios; ficando livre a cada Estado o arbitrio de manter os futuros ministros desse ou de outro culto, sem contravenção do disposto nos artigos antecedentes. Art. $7^{\circ}$ Revogam-se as disposições em contrario". Do texto (e especialmente dos arts. $1^{\circ}$ e $2^{\circ}$, que destaco pela semelhança com o cerne das disposições atuais acerca do tema), pode-se observar que, sob os primeiros raios da república brasileira, já se havia consagrado em âmbito normativo o respeito à liberdade de crença, e foi sob essa influência longínqua que a Constituição Federal de 1988 fez clarividente em seu texto a proteção à liberdade de crença, sob as variadas nuances desse direito. De fato, como salienta Sergio Gardenghi: "Não há, com efeito, uma única liberdade religiosa na Constituição de 1988, mas sim uma plêiade de posições jurídicas do indivíduo e das organizações religiosas em face do Estado e dos demais particulares. Essas posições jurídicas podem ser agrupadas em quatro dimensões distintas, a saber: a) liberdade de consciência religiosa ou liberdade de crença (art. $5^{\circ}$, inciso VI, primeira parte); b) liberdade de culto (art. $5^{\circ}$, inciso VI, fine); c) liberdade de associação religiosa (art. $5^{\circ}$, incisos XVII a XX); d) liberdade de comunicação das ideias religiosas (art. $5^{\circ}$, IX, c.c. o art. 220)" (Suiama, Sergio Gardenghi. Limites ao Exercício da Liberdade Religiosa nos Meios Comunicação de Massa. Disponível em: http://www.prsp.mpf.mp.br/prdc/area-de-

atuacao/digualdetnraclibrel/Artigo $\% 20$ -

\%20Limites \%20ao\%20Exercicio\%20da\%20LIberdade\%20Religiosa\%20nos \%20Mei.pdf. Acesso em 9/12/2016) Sob essa ampla compreensão da proteção constitucional à liberdade de crença, torna-se claro que as previsões normativas constantes da lei ora combatida, pretensamente voltadas à defesa da liberdade de crença religiosa e à liberdade de manifestação dessa crença, atingem, a um só tempo: (i) a laicidade do Estado; (ii) a própria liberdade de consciência e de crença e (iii) o correspondente direito à descrença religiosa e à manifestação dessa descrença. Com efeito, a Lei $\mathrm{n}^{\circ} 1.515 / 15$ prevê proteção diferenciada a uma forma específica de pensamento religioso, o cristianismo, que passa a dispor de um status diferenciado no universo das crenças religiosas, fazendo a previsão normativa em questão se assemelhar a uma aproximação do estado com aquele credo, o que é vedado pela Constituição Federal de 1988, em várias de suas passagens, mas de modo expresso no art. 19, I. Vide: “Art. 19. É vedado à União, aos Estados, ao Distrito Federal e aos Municípios: I estabelecer cultos religiosos ou igrejas, subvencioná-los, embaraçar-lhes o funcionamento ou manter com eles ou seus representantes relações de dependência ou aliança, ressalvada, na forma da lei, a colaboração de interesse público"; Como destacado pelo Ministro Celso de Mello, no julgamento da $\mathrm{ADI}^{\circ}$ 3.510/DF, Pleno, Relator o Ministro Ayres Britto, DJe de 28/5/10, "A laicidade do Estado, enquanto princípio fundamental da ordem constitucional brasileira, que impõe a separação entre Igreja e Estado, não só reconhece, a todos, a liberdade de religião (consistente no direito de professar ou de não professar qualquer confissão religiosa), como assegura absoluta igualdade dos cidadãos em matéria de crença, garantindo, ainda, às pessoas, plena liberdade de consciência e de culto. O conteúdo material da liberdade religiosa compreende, na abrangência de seu significado, a liberdade de crença (que traduz uma das projeções da liberdade de consciência), a liberdade de culto e a liberdade de organização religiosa, que representam valores intrinsecamente vinculados e necessários à própria configuração da idéia de democracia, cuja noção se alimenta, continuamente, dentre outros fatores relevantes, do respeito ao pluralismo. Nesse contexto, e considerado o delineamento constitucional da matéria em nosso sistema jurídico, impõe-se, como elemento viabilizador da liberdade religiosa, a separação institucional entre Estado e Igreja, a significar, portanto, que, no Estado laico, como o é o Estado brasileiro, haverá, sempre, uma clara e precisa demarcação de domínios próprios de atuação e de incidência do poder civil (ou secular) e do poder religioso (ou espiritual), de 
tal modo que a escolha, ou não, de uma fé religiosa revele-se questão de ordem estritamente privada, vedada, no ponto, qualquer interferência estatal, proibido, ainda, ao Estado, o exercício de sua atividade com apoio em princípios teológicos ou em razões de ordem confessional ou, ainda, em artigos de fé, sendo irrelevante - em face da exigência constitucional de laicidade do Estado - que se trate de dogmas consagrados por determinada religião considerada hegemônica no meio social, sob pena de concepções de certa denominação religiosa transformarem-se, inconstitucionalmente, em critério definidor das decisões estatais e da formulação e execução de políticas governamentais.

O fato irrecusável é que, nesta República laica, fundada em bases democráticas, o Direito não se submete à religião, e as autoridades incumbidas de aplicá-lo devem despojar-se de pré-compreensões em matéria confessional, em ordem a não fazer repercutir, sobre o processo de poder, quando no exercício de suas funções (qualquer que seja o domínio de sua incidência), as suas próprias convicções religiosas." No mesmo sentido, assentou o Ministro Marco Aurélio, no voto condutor da $\mathrm{ADPF} n^{\circ} 54 / \mathrm{DF}$, que "o Estado não é religioso, tampouco é ateu. O Estado é simplesmente neutro. (...) Se, de um lado, a Constituição, ao consagrar a laicidade, impede que o Estado intervenha em assuntos religiosos, seja como árbitro, seja como censor, seja como defensor, de outro, a garantia do Estado laico obsta que dogmas da fé determinem o conteúdo de atos estatais. Vale dizer: concepções morais religiosas, quer unânimes, quer majoritárias, quer minoritárias, não podem guiar as decisões estatais, devendo ficar circunscritas à esfera privada. A crença religiosa e espiritual - ou a ausência dela, o ateísmo - serve precipuamente para ditar a conduta e a vida privada do indivíduo que a possui ou não a possui. Paixões religiosas de toda ordem hão de ser colocadas à parte na condução do Estado"(Pleno, DJe de 30/4/13). De outro lado, as normas insertas na Lei $\mathrm{n}^{\mathrm{o}} 1.515 / 15$ violam também a liberdade de consciência e de crença (art. $5^{\circ}$, inciso VI) e a liberdade de expressão (art. $5^{\circ}$, inciso IX). Consoante adverte José Afonso da Silva, a liberdade religiosa compreende não apenas: "a liberdade de escolha da religião, a liberdade de aderir a qualquer seita religiosa, e a liberdade (ou o direito) de mudar de religião, mas também (...) a liberdade de não aderir a religião alguma, assim como a liberdade de descrença, a liberdade de ser ateu e de exprimir o agnosticismo" (SILVA, José Afonso. Curso de Direito Constitucional Positivo, 36 ed. São Paulo: Malheiros, 2013. p. 250). O direito à liberdade de crença, portanto, guarda íntima relação com o direito à manifestação do pensamento, seja do pensamento religioso, seja das ideias agnósticas, sendo um contrassenso que a exteriorização do pensamento seja tolhido em nome da proteção da liberdade de crença, reduzida que ficaria em uma de suas facetas. Não por acaso, o dispositivo legal que protege a liberdade de crença protege igualmente a liberdade de consciência. Vide: Art. $5^{\circ}$ (...) VI - é inviolável a liberdade de consciência e de crença, sendo assegurado o livre exercício dos cultos religiosos e garantida, na forma da lei, a proteção aos locais de culto e a suas liturgias; A proteção constitucional, portanto, é ampla e não contrapõe a crença à descrença, mas antes as iguala, de modo que há direito de crer, mas há também (e no mesmo patamar constitucional) o direito de questionar as próprias crenças, de modificá-las, de substituí-las. E esse direito, associado ao direito à livre manifestação do pensamento, traduz a impossibilidade de o Estado proibir a exteriorização do questionamento, mesmo que de faceta religiosa, já havendo esta Corte assentado que a liberdade de manifestação do pensamento alberga, inclusive, a crítica contundente, de modo que não pode ser tolhida a priori, ainda que a crítica esteja voltada à opinião defendida pela maioria do corpo social.

Assim, a lei em comento, em seu art. $3^{\circ}$, ao atribuir correspondência entre a conduta, genericamente considerada, de "discriminação ao Cristianismo" e a prevista no artigo 208 do Código Penal Brasileiro ("Escarnecer de alguém 
publicamente, por motivo de crença ou função religiosa; impedir ou perturbar cerimônia ou prática de culto religioso; vilipendiar publicamente ato ou objeto de culto religioso"), invadiu esfera reservada à União para legislar sobre Direito Penal. De fato, a pretexto de consagrar a legislação nacional - o que se mostra configurado na expressão "conforme prediz o artigo 208 do Código Penal Brasileiro" - o dispositivo constante do art. $3^{\circ}$ da Lei ${ }^{\circ} 1.515$, de 30 de junho de 2015 predefiniu, como criminosa, conduta ("discriminação ao Cristianismo") que não resta explicitamente descrita, sob todas as suas formas, no artigo penal citado, que possui núcleos do tipo precisamente definidos. São eles: (i) "escarnecer de alguém publicamente, por motivo de crença ou função religiosa"; (ii) impedir ou perturbar cerimônia ou prática de culto religioso; e (iii) vilipendiar publicamente ato ou objeto de culto religioso. Consoante aponta Fernando Capez: “(...) Cumpre ressalvar que a ofensa à religião em si mesma, sem que haja ofensa direta a uma pessoa, não configura o crime em tela. Assim, segundo sustenta Hungria, 'o escárnio dirigido aos católicos ou protestantes em geral não constitui o crime em questão"" (Curso de Direito Penal. volume 2, parte especial. 14. ed. São Paulo: Saraiva, 2014). Resta, destarte, evidenciado que o art. $3^{\circ}$ da Lei municipal $n^{\circ} 1515 / 15$ não corresponde a mera repetição do tipo penal inserto no art. 208 do CPB, mas sim inovação na ordem jurídica em matéria de competência exclusiva da União. É caso, portanto, de urgência na suspensão da Lei no 1.515 , de 30 de junho de 2015, pois seu texto impacta sobremaneira no exercício do direito de liberdade, não apenas impedindo o seu pleno exercício, mas também apontando-o como crime sem correspondência na legislação nacional. Utilizome, desse modo, da possibilidade concedida pelo art. $5^{\circ}, \S 1^{\circ}$, da Lei federal $n^{\circ}$ 9.882/99, para conceder a medida cautelar pleiteada, ad referendum do Plenário, suspendendo a eficácia da Lei no 1.515 , de 30 de junho de 2015 , do Município do Novo Gama. Por razões de celeridade processual, solicito, desde já, as informações aos requeridos, no prazo de 10 dias (art. 12 da Lei 9.868/99). Após, abra-se vista, sucessivamente, no prazo de cinco dias, ao AdvogadoGeral da União e ao Procurador-Geral da República. Publique-se. Brasília, 14 de dezembro de 2016. Ministro Dias Toffoli Relator Documento assinado digitalmente

(ADPF 431 MC, Relator(a): Min. DIAS TOFFOLI, julgado em 14/12/2016, publicado em PROCESSO ELETRÔNICO DJe-268 DIVULG 16/12/2016 PUBLIC 19/12/2016)

Esta ADPF 431 foi extinta sem julgamento do mérito finalmente, pelo município de Nova Gama/GO ter revogado expressamente a lei 1.515/15 com a Lei municipal $\mathrm{n}^{\circ}$ $1.582 / 16$.

Outros julgados trataram do tema em comento, mas neste estudo apresentaremos apenas estes, sendo que outros poderão ser futuramente tratados. Lembrando que no momento aguardamos o julgamento do processo relacionado ao sacrifício de animais em rituais de religiões afro-descendentes o Recurso Extraordinário 494601. E a Ação Direta de Inconstitucionalidade (ADI) 4439, ajuizada pela Procuradoria Geral da República (PGR), e que questiona o ensino religioso confessional - aquele vinculado a uma religião específica, nas escolas da rede oficial de ensino do país. A PGR defende que o ensino 
religioso deve ser ministrado de forma laica, sob um contexto histórico e abordando a perspectiva das várias religiões.

\section{Os diferentes graus de eficácia das normas constitucionais}

Para Ferrari, em comunicação oral, expõe que as normas não possuem aplicação plena, porém possuem um mínimo de eficácia, que acaba se refletindo, não só em suas relações inter normativas, como também à realidade social. A partir daí, percebemos a necessidade de observar, segundo a autora, que, "a medida do mínimo de eficácia pode caracterizar uma diferença na graduação da capacidade de concretização da norma e que não é correto pensar que tais normas sejam de eficácia diferida, isto é, que nada significam enquanto o legislador não emitir regras jurídicas para complementá-las". ${ }^{28}$ Kelsen, que após tratar a validade como propriedade de relação entre normas, pôde afirmar que "pode existir uma certa conexão entre vigência (no sentido de validade) e eficácia, posto que uma norma jurídica só pode ser considerada como objetivamente válida, quando a 'conduta humana que ela regula lhe corresponde efetivamente'. Uma norma que nunca e em parte alguma é aplicada e respeitada, não é eficaz e, em certa medida, não será considerada como norma válida (vigente). 'Um mínimo de eficácia é a condição de sua vigência', pois uma norma que nunca e em parte alguma é aplicada e respeita, não poderá ser considerada como válida". ${ }^{29}$ Meirelles Teixeira, citado por Regina Nery Ferrari, afirma que "cumpre ao intérprete aplicador da Constituição procurar sempre dar aos dispositivos desta o máximo de efeitos possível, na medida em que a universal inoperância dos corpos legislativos acabaria por transformá-las em letras mortas. Apresenta, então, o seu mínimo eficácia como conseqüência jurídica imediata das normas constitucionais de eficácia ou aplicabilidade limitada:

a) ordem para que o legislador legisle para o fim determinado;

b) o condicionamento da legislação futura, pois todas as normas constitucionais, mesmo as de eficácia limitada, são condicionantes da legislação infraconstitucional;

c) a revogação das leis anteriores incompatíveis, por inconstitucionalidade

\footnotetext{
28 FERRARI, Regina Maria Macedo Nery. Normas Constitucionais Programáticas. Normatividade, Operatividade e Efetividade. p. 141.

29 FERRARI, Regina Maria Macedo Nery. Normas Constitucionais Programáticas. Normatividade, Operatividade e Efetividade. p. 142 - 143.
} 
superveniente;

d) a eficácia interpretativa integradora;

e) o condicionamento da atividade discricionária da Administração e do Poder Judiciário, pois que a força vinculante das normas constitucionais e, dentre elas, as que necessitam de complementação ou regulamentação, não se restringem apenas à atividade do Poder Legislativo (grifo nosso);

f) a criação de situações jurídicas subjetivas de vínculo ou de vantagem. Sendo que esse representa o ponto mais relevante e árduo do tema, pois sendo pouco versado, faz com que esteja longe de posicionamentos firmes e soluções definitivas.

Como já mencionamos no início do capítulo, todas as normas constitucionais possuem alguma eficácia, que acarretam efeitos diversos no mundo jurídico, principalmente no que se refere a relação inter normativa, quando revoga a legislação com ela incompatível. E no que se refere a este mínimo de eficácia da norma constitucional, devemos expressar além de um juízo de valor a constatação de uma realidade jurídica, pois a partir do momento que o constituinte determina a necessidade de uma complementação integrativa, esta impede comportamentos contrários ao que este estabelece, e por conseqüência, que nenhuma lei possa restringir este direito assegurado, até o ponto que este possa ser eliminado.

Para Regina Ferrari, “a omissão do legislador na criação da norma regulamentadora integrativa leva 'à existência de um direito destituído de qualquer garantia, isto é, sem ação' e a 'subversão da hierarquia das normas, com a falência da supremacia constitucional, visto que o legislador ordinário se arroga o poder de impedir que um direito conferido pela Lei maior opere seus efeitos". ${ }^{30}$

É necessário, que, ao tratar das normas constitucionais de eficácia limitada ou reduzida, num determinado grau, leve-se em conta a necessidade de regulamentação integrativa, observar o ponto de vista de Jorge Miranda, que a partir da idéia de Canotilho, afirma que "uma vez concretizada a norma constitucional mediante normas legais, essas não podem ser, pura e simplesmente revogadas, o que levaria ao retorno à situação anterior, isto é, para antes da existência da norma regulamentadora. É claro que o

30 TEIXEIRA, Meirelles. In: FERRARI, Regina Maria Macedo Nery. Normas Constitucionais Programáticas. Normatividade, Operatividade e Efetividade. 
legislador tem a faculdade de modificar qualquer regime jurídico por ele criado, mas, 'o que não tem é a faculdade de subtrair superveniente a uma norma constitucional e exeqüibilidade que esta tenha, entretanto, adquirido', o que justificaria reclamar judicialmente a manutenção do nível de realização".31

\section{Conclusão}

Mediante este estudo apresentado acima, confirmo com pensamento de Rodrigues quando afirma sobre a dissertação "Limites a intervenção do Estado ao Direito de Liberdade Religiosa de Crianças e Adolescentes Orientados pelos Pais”, uma vez que ela defende que o indivíduo deve ter liberdade para realizar suas crenças.

Analisando o grau de eficácia das normas constitucionais, com o raciocínio da Dra. Regina Maria Macedo Nery Ferrari que lhes atribui (a todas) um mínimo de eficácia chegamos a ponto das conclusões.

Diante o exposto, pode-se concluir que:

1- A Liberdade Religiosa é um Direito Fundamental, de eficácia contida e aplicabilidade direta, imediata, mas possivelmente não integral;

2 - Os Direitos Fundamentais, tais como Direito de Defesa só podem ser limitados por outro de igual ou maior importância;

3- No caso das normas de eficácia contida a lei não pode restringir onde a Constituição, não restringe, então devemos fazer a interpretação sistemática da mesma, visto que, as limitações aos Direitos Fundamentais devem ser analisados restritivamente Segundo J. J. Gomes Canotilho, Anna Candida da Cunha Ferraz, dentre outros.

Vimos que:

3.1 A liberdade religiosa foi relativizado pelo direito ao silêncio dos moradores vizinhos ao templo.

3.2 A jurisprudência é pacífica no sentido de havendo colisão entre o direito de liberdade religiosa e o direito à vida, prevalece o direito à vida. Pois, sem a vida nenhum outro direito se realiza.

3.3 No que tange à criminalização de condutas, a competência é privativa da União, art. 22 da Constituição.

\footnotetext{
${ }^{31}$ FERRARI, Regina Maria Macedo Nery. Normas Constitucionais Programáticas. Normatividade, Operatividade e Efetividade. . 148
} 
82 


\section{Referências}

ALEXY, Robert. Teoría de los derechos fundamentales. Madrid: Centro de Estudios Políticos y Constitucionales, 2001.

ALVES, Rubem A. O que é religião? Editora Brasiliense, 1984

ACQUAVIVA, Marcus Cláudio. Dicionário Jurídico Brasileiro Acquaviva. São Paulo: Editora Jurídica Brasileira, 1998.

BASTOS, Celso. Curso de Direito Constitucional. São Paulo: Saraiva, 1990. p. 114 et seq In: GODOY, Arnaldo Moraes. A Liberdade Religiosa nas Constituições do Brasil. São Paulo: Editora Revista dos Tribunais, 2001.

BONAVIDES, Paulo. Curso de Direito Constitucional. São Paulo: Malheiros, 2000.

BOBBIO, Norberto. Teoria do Ordenamento Jurídico. 10. ed. (tradução de Maria Celeste C. J. Santos). Brasília: Editora Universidade de Brasília, 1997.

CANOTILHO, J.J. Gomes. Direito Constitucional e Teoria da Constituição. Coimbra: Almedina, 1999.

CRETELLA Júnior, José. Comentários à Constituição de 1988, p. 216. In: Exercício da Liberdade Religiosa. Maria Luiza Whately Barretto.

DOTTI, René Ariel. Declaração Universal dos Direitos do Homem e Notas da Legislação Brasileira. Curitiba: JM Editora, 1999.

FERRARI, Regina Maria Macedo Nery. Normas Constitucionais Programáticas. Normatividade, Operatividade e Efetividade. São Paulo, Editora Revista dos Tribunais, 2001.

Ferraz, Anna Candida da Cunha. "O ensino religioso nas escolas públicas: exegese do parágrafo $1^{\circ}$ do art. 210 da CF de 05.10.1988”. Revista dos Tribunais. Ano 5. No 20. Jul/ set de 1997. Cadernos de Direito Constitucional e Ciência Política.

FERREIRA, Aurélio Buarque de Holanda. Novo Dicionário Aurélio. São Paulo: Nova Fronteira, 1975.

GODOY, Arnaldo Moraes. A Liberdade Religiosa nas Constituições do Brasil. São Paulo: Editora Revista dos Tribunais, 2001.

MENCK, José Theodoro Mascarenhas. A Liberdade Religiosa e o Parlamento Imperial Brasileiro (1823 a 1889)

MODERNO DICIONÁRIO ENCICLOPÉDICO BRASILEIRO. Curitiba: Editora Educacional Brasileira, 1985.

MORAES, Alexandre de. Direito Constitucional. São Paulo: Editora Atlas, 1999.

NAKAHIRA, Ricardo. Eficácia Horizontal dos Direitos Fundamentais . Em, https://sapientia.pucsp.br/bitstream/handle/7752/1/Ricardo\%20Nakahira.pdf

consultado em 10 de junho de 2017.

NOVELINO, Marcelo. Direito Constitucional. São Paulo: Editora Método, 2009, $3^{\circ}$ ed.

PIOVESAN, Flávia. Direitos Humanos e o Direito Constitucional Internacional. São Paulo: Max Limonad, 2000.

SARLET, Ingo Wolfgang. A Eficácia dos Direitos Fundamentais. Porto Alegre: Livraria do Advogado, 2001.

SARLET Wolfgang, Liberdade religiosa e dever de neutralidade estatal na Constituição Federal de 1988. Em,

http://www.conjur.com.br/2015-jul-10/direitos-fundamentais-liberdade-religiosa-deverneutralidade-estatal-constituicao-federal-1988, consultado em 15 de junho de 2017. 
SCAMPINI, Pe. José . A Liberdade Religiosa nas Constituições Brasileiras. Petrópolis: Vozes, 1978.

SILVA, José Afonso da. Curso de Direito Constitucional Positivo. São Paulo: Saraiva, 1995.

Links:

A Constituição e o Supremo:

http://www.stf.jus.br/portal/constituicao/constituicao.asp e

http://redir.stf.jus.br/paginadorpub/paginador.jsp?docTP=AC\&docID=595444

consultado em 02 de abril de 2017.

http://www.stf.jus.br/portal/constituicao/constituicao.asp e

http://redir.stf.jus.br/paginadorpub/paginador.jsp?docTP=AC\&docID=595444

consultado em 02 de abril de 2017.

http://www.nupper.com.br/home2/?page $\mathrm{id}=116$

Recebido: 19/10/2017

Received: 10/19/2017

Aprovado: $23 / 11 / 2017$

Approved: 11/23/2017 